International Journal of Advanced Studies in Humanities and Social Science (IJASHSS)

Available online at http://www.ijashss.com

Volume 8, Issue 4 (2019) pp. 350-361

Original Article

\title{
The Evaluation and Comparison of People's Role in Two Doctrines of Jurist Absolute Mandate and Proxy of Jurist
}

\author{
Saeed Abdollahyar ${ }^{* 1}$, Alireza Masihpoor ${ }^{2}$ \\ ${ }^{1}$ Department of law, Payame Noor University, PO Box 19395-3697Tehran, I.R of Iran \\ ${ }^{2}$ M.A. in the field of law
}

Corresponding Author E-mail: abdollahyar saeed@yahoo.com

Received: 24 October 2018, Revised: 05 December 2018, Accepted: 20 December 2018

\section{ABSTRACT}

Several theories have been on regarding type and quality of government and politics in the history of Islamic jurisprudence and political doctrines. Theories of jurist absolute mandate, or jurist general authority, and proxy of jurist, the prudent authority, are some of these doctrines. Theory of jurist absolute mandate as the concept of authority over leadership in Muslim community has been confirmed by majority of Islamic jurisprudents from the beginning while doctrine of jurist's proxy has a short history and has been posited by some researchers at present time. Comparing these two doctrines, we imply that in theory of jurist absolute mandate, immediate divine legality and God's governance right have caused people to play the role at phase of realization of the government. However, they play essential and determinant role at the stage of enforcement of power and governance. In contrast, public legitimacy and right governance over people is the main basis for theory of jurist's proxy. Given that in this theory since people are joint owners of their land and living place, they assign right of governance of their land through proxyship to another person or group in order to manage the aforesaid living settlement for symbiosis and peaceful wellbeing of citizens. Therefore, according to this doctrine, one could assume an original and essential role for the people both at phase of creating the government and at the stage of power enforcement.

Keywords: Jurist Absolute Mandate, Proxy of Jurist, Power Enforcement, Government.

\section{Introduction}

At time of Disappearance of Imam Zaman (AJ), one of the foremost concerns for Shiites is the question about government over the community; namely, is establishing government by Shiites is required during Imam's Disappearance? What is the goal of establishing such a government? In the case of permission for establishing a government, who will rule and what is the basis for legitimacy of ruler? What are the qualifications and characteristics of the ruler? What role may the people play in the government? And the similar questions like of these kinds. The main topic in presentation of such questions is to interpret theoretically and 
to explore various purposed theories in the field of political doctrine. The present essay is trying to investigate and data mining and comparing among the posited theories in history of political doctrine namely two theories of "Jurist Absolute Mandate" and "the Prudent Proxy"1 in terms of the role that people may play in each of these two doctrines in the position of creating and realization of government as well as participation in administration of the government. Accordingly, the research main question here is "what are the consequent effects of each of the above-said doctrines and people's position in two subjects of government realization and enforcement (participation)?" As the first answer to this question, it can be expressed that principally in doctrine of jurist absolute mandate, people play no role in legitimacy of the government (and mandate), but they may play essential role in realization, proving, continuance, and participation in governance and in contrast in theory of jurist's proxy, the people's role is considered as basic and original in legality and enforcement of the government.

To explore this subject better, we will organize these subjects into two parts. At first part, we will examine people's role at

1 - Due to normative overlooking and considerations, this theory is called the jurist's proxy in this study and this doctrine was purposed by Dr. Mehdi Hayeri Yazdi so the reason for normative overlooking and considerations is in that according to attitude of the founder of the aforesaid doctrine, even a jurist who governs over the society has no right to rule over the community solely for which he is a jurist and basically jurisprudence attribute is not subjected to rule over the society but since it is possible that the people to assign the proxyship to a person that they consider him as prudent and wise for statesmanship at certain time in order to assume the responsibility of leadership in the society and such a person may be accidentally a jurist so this theory is also called as jurist's proxy. the stage of acquisition and realization of power and government and then the role of people will be investigated at participation phase in power enforcement and the governance.

\section{Role of People in Acquisition and Realization of Power and Governance}

Rationally and logically, the first role, assumed for the members of a community, is their role in realization and establishment of a government. Thus, it is deemed duly first to evaluate and compare the role of people at this step in each of two theories of jurist absolute mandate and jurist's proxy.

\section{- Role of People in Realization of Government in Doctrine of Jurist Absolute Mandate}

In doctrine of jurist absolute mandate, people have no role in legitimacy of government and mandate by fullyqualified jurist (Faqih Jami al-Sharayet) since legality of government and mandate in this theory is exclusively caused by God's order and ordain. The Islamic jurisprudence (jurist mandate) in administration of governmental system has been appointed by the holy Sharia like position of judgment and post of his religious authority and people's acceptance is effective at proving stage not principally in demonstration of such a position. In other words, the fully qualified jurist who is competent to order fatwa has the position of issuance of fatwa whether someone accepts his religious authority or not so Islamic jurisprudent is the same. The only difference among them is the point that if the authority of a jurist was accepted by people, the extra position of his authority for governance will be actually realized followed by some objective effects otherwise this authority will remain as a potential and it does not 
result in any external effect. The Islamic jurisprudence trend is also the same in relation to administration of Islamic Community (Umma) affairs; namely, the original position is reserved and realization of external effects will be subjected to people's sponsorship (Javadi Amoli, 1993).

Although in theory of jurist absolute mandate the people has no role in legality and proving the position of Islamic jurist (Velayat-E-Faqih), they may play an essential role in the establishment of government by Islamic jurist and realization of government externally, its acceptance, compliance and allegiance, continuance, and supervision and overthrowing the government while under no condition from the aforesaid cases the ruler shall not be legally entitled to enforce coercion and compulsion to impose the mandate. As Imam Khomeini has expressed: "The sponsorship for Muslim affairs and establishment of government is subjected to majority votes of Muslim people, which has been mentioned in Constitution and it has been interpreted as allegiance with Muslim authority at Islamic early period" (Moosavi Khomeini, 2006).

To prove and demonstrate the importance of the above-said claim, one can refer to two reasons:

- According to a narrative, Holy Prophet (PBUH) told to Imam Ali (PBUH): "Oh son of Abu-Taleb! Authority over my community belongs to you. If they accept peacefully and without conflict) your mandate and agree with your (government), assume administration of their affairs and if they disagreed with you, leave it to them" (Noori; 1988). In this narrative, Holy Prophet (PBUH) assumes authority over Islamic community as a fixed mandate and right for Imam Ali (PBUH) then he conditions raising by the order of Umma and establishing of Islamic government as subjected to their acceptance and agreement. Further, in order to emphasize this issue, he adds that if the Islamic community (Umma) disagreed with you, should leave it to them. Also, casting a glance at Imam Ali's (PBUH) conduct, we can see that Imam acted exactly according to what Holy Prophet (PBUH) had stated and he never imposed his own as a ruler to the people and after demise of Holy Prophet (PBUH), when some group diverted caliphate (government) from its proper and original route, Imam Ali (PBUH) did not tend to acquire caliphate coercively, rather by going to houses of Mohajerin (Mecca Immigrants) and Ansar (Prophet's helpers in Medina) reminded them of his authority and asked them to do their task in assisting him to uphold Islamic justice government but they only affirmatively promised to him for their assistance and they did not fulfill their religious duty. As a result Imam Ali gave up the power as well while he could take militarist measures, he avoided this action but he was prepared to accept caliphate when he saw the extensive rushing people and their persistence to accept his government and acquired their compliance regarding caliphate, he did so as he mentioned:

"Beware! By God who cleaved the seed and created the human, if there was not the attendance of present people and if divine authority was not fulfilled with the presence of helpers and if there was not this treaty between scholars with God that they should not tolerate and be patient to satiety of tyrants and hungry of the oppressed, certainly I would have left the reign of ruling on the back of its camel and quenched the last of them with their first cup so you could see that this world is inferior than the nasal rheum of a female goat before me". ${ }^{2}$ In another place, Imam

(Nahjolbalagheh: oration: 3) 
Ali (A.S) expresses: "We have every right (in caliphate affair), the better if this right was given up to us; unless otherwise, (we do not seize it by coercion, but) we ride on camels even though nightly trip lasts for a long time".

- Establishment and continuance of a government based on coercion and without people's agreement may cause shaking the pillars of ruling rather than making the people pessimist toward the government and its leadersIt is obvious that it is not possible to accept establishing an Islamic government or its continuance at the price of people's pessimism to Islamic religion and thus reducing religious influence and effect on people since the establishment of Islamic government is aimed at spreading of Islam among the people and leading them to individual and social perfection and prosperity and at the same time it is clear that such an objective will not be realized without people's satisfaction. As a result, if establishment and or continuance of Islamic government may not be followed by public agreement, it will then lead to a paradoxical intent and losing religious goals. Thus, this is not certainly appropriate (Arasta, 2005).

Also in the field of legislation, some articles in Constitution of Islamic Republic of Iran refer to people's role in realization of government and governance over their destiny including first article of Constitution accordingly it states: "Form of government of Iran is that of an Islamic republic, endorsed by the people of Iran on the basis of their long-standing belief in the sovereignty of truth and Quranic justice. This was confirmed through a majority of $98.2 \%$ of eligible voters in the referendum of 9 and 10 Farvardin, $1358 \mathrm{H}$. Sh., corresponding to 1 and 2 Jamadi alAwwal, 1399 H. [29 and 30 March 1979], held after the victorious Islamic
Revolution led by the eminent marja 'Taqlid, Ayatollah al-'Uzma Imam Khomeini". Similarly, Clause VIII from Article 3 has expressed providing all facilities toward public participation by people in determination of their own political, economic, social, and cultural destiny as one of duties and responsibilities of the government.

\section{- Role of People in Realization of Doctrine of Jurist's Proxy}

In Jurist's proxy doctrine, according to its interpreter, government is not meaningful and real without agency and representation thus both origin of legality and source of realization and acceptability of power and government are nothing except for people's wish and will. As Dr. Hayeri Yazdi states:

"Only the people shall identify the members of government and elect them for state political ruling the same as they try to manage well-being and their family so they should recognize the most perfect and qualified person(s) for government that are probably the prophet or Imam ... The relation between people of the country with government and statesmanship position is exactly similar to joint owners, who elect a person as their own advocate and fully-power agent. As a result, government is not meaningful and real without people's agency and representation." (Hayeri Yazdi, 1994).

As a summary of this part, it can be implied that legality of jurist government and mandate is caused by God's order and ordain in theory of jurist's absolute mandate while in doctrine of jurist's proxy, it is originated from people's will and wish or majority of them and at the same time, proving, establishment, objective realization, acceptability, authority, and stability of government by the people are the commonalities between two doctrines 
so the government shall not be entitled to impose oneself to people by coercion and deception.

\section{Role of People at Phase of Participation in Power Enforcement and Governance}

After evaluation and comparison of the role of people in two doctrines of jurist absolute mandate and proxy of jurist at stage of realization and establishing the government, now we compare the next role of people i.e. playing a role at the stage of power enforcement and government in each of both theories.

\section{- Role of People in Participation in the Government in Doctrine of Jurist Absolute Mandate}

In this theory, religious government is sponsor and responsible for addressing important material and spiritual affairs in the community and protection and administration of government are considered as foremost issues for Muslims, thus it can be mentioned that protection from religious government is one of the most crucial and important obligations and dealing with this issue is therefore necessary. Dealing with the government means to establish it and also cover the constant legality and effectiveness of the government. The constant presence of people in the field of politics and proper use of their political freedom is requisite for such an endeavor.

In this regard, Ayatollah Javadi Amoli expresses: "Islamic nation is administered when people feel sense of freedom and have right of selection and their vote and right to be respected. For this reason, Almighty God told the Holy Prophet (S) in Quran "Consult with them in affairs (of governance)..."3; Islamic system is a system of counseling with people and with the

( Quran,3) folks. They consult with the people in all affairs and with expert representatives of people in technical and professional affairs. Voting by people is in fact consultation with the people. They elect the president and choose representatives in Expert Assembly and Islamic Parliament of Iran; however, in order to legalize this system in general, first the competency of candidates in Expert Assembly and Islamic Parliament of Iran as well as of presidential candidates should be confirmed by the bodies which appointed by the leader, so under such conditions both legality is demonstrated and the prestige of people's freedom will be reserved; otherwise, the Islamic system will not be stabilized and survived. One who does not respect public votes will not possess national power." (Javadi Amoli, 1993).

Article 6 of Constitution is one of the paramount principles referring to people's participation in enforcement of the government: “The country's affairs in the Islamic Republic of Iran must be managed on the basis of public opinion as expressed through elections, including the election of the President, the representatives of the Islamic Parliament of Iran, and the members of the councils, and the like, or through referenda, in cases specified in other articles of this law." In theory of jurist absolute mandate, the role of people in political participation and administration of government and its necessity may be justified and defined with respect to some Islamic teachings. For example, one can refer to three Islamic principles in this sense. Those three principles are as follows:

1. Principle of council;

2. Principle of Enjoining of the goods and forbidding of the evils (Amr Be-Maaroof VA Nahye- AZ Monkar); and, 3. Advice. 
The three above principles are considered as regulatory fundamentals and elements in controlling power and monitoring over the government rather than participatory aspect. Likewise, in addition to above-said items, political freedoms such as liberty of parties, freedom of expression and press are also some of the components of people's political participation and their supervision over the government, which have been adequately addressed in theory of jurist absolute mandate and IRI Constitution. In this part, only principle of counsel is explored in people's political participation for the sake of brevity.

\section{Role of People in Political Participation Based on Principle of Counsel}

It is therefore an obligatory task to observe Muslim expediency by all directors and agents in Islamic system and doing of this task is not possible on many occasions without consultation with prudent members and experts. This point that in many cases recognition of expediency is only possible through consultation is of the clear subjects that do not to need reasoning; especially, at present when the government has widely expanded and its administration requires having various knowledge and skills. Doubtlessly, since the manager does not usually possess totally all these sciences, s/he has to inevitably consult with the experts in those cases (Arasta, 2005).

Likewise, consultation in the holy verse "Consult with them in affairs (of governance)" means that it was obligatory task for the Holy Prophet (S) to consult with his companions. It can be concluded from this point here that consultation in several affairs is also mandatory for Prophet's (S) successors and next leaders of Islamic community namely Pure Imam (PBUT) as well as fully- qualified jurists and also all directors and decision makers since the Holy Prophet (S) with divinely knowledge and lack of need to advice has been ordered to consult with his companions. The other people (particularly rather than Innocent Imams) will be obliged to consult with experts and their advice as a fortiori.

The point, which is duly to deal with in this discussion, is the interpretation and position of principle of counsel in theory of jurist absolute mandate and determination of affairs that the Islamic jurist should deal with them by implementation of authority and governance in them based on principle of counsel. Allameh Tabatabaei writes:

"The orders which are issued by jurist position will be enacted through consultation and with observance of their expediency for Islam and Muslims "Consult with them in affairs (of governance)" and it is clear that this conduct is an introduction for a tradition and trend which does not result in disagreement with the discretion of any community among several societies and for this reason it could not be changed. It is therefore one of the secondary instinctive rule and Islam verifies it" (Tabatabaei, 2003)

According to theoretical bases of Islamic jurisprudence, there are three types of properties and affairs in a country: personal properties and affairs, public properties and affairs, and governmental authoritarian and religious properties and affairs where God has given the people freedom and right to own in two fields of private and public affairs while in those properties that belong to government and religious belief such as war spoils (Anfal) and the like, these affairs are directly related to Imam in Islamic community and rather than exclusive financial affairs for imamate, the Islamic injunctions, limits, discretionary punishments, and divine rules are also 
related to the Islamic religion and Sharia so people may not possess or interfere with these affairs. Thus, people are mature, obliged, and non- minor in their private affairs and public activities of the country as well as its construction and cultivation and also acquisition of their rights (Javadi Amoli, 1993).

Since these subjects are God's affairs (Amrollah), namely the area of divine rules, Islamic jurist and leader of the Islamic community only notices God's order and divine command in order to fulfill them so he may neither change nor alter religious injunctions by his vote and not with people's opinion; this area is concerned with principle of realization and stability of divine rules so the jurist is not entitled to decrease and increase them as Holy Prophet (S) and Pure Imam (A) had no such a right as Holy Quran referred to this point: "You have no concern in the affair..." (Family of Imran 3:128) and "And it behooves not a believing man and a believing woman that they should have any choice in their matter when Allah and His Apostle have decided a matter;..." (Quran, 33).

However, where this subject is people's affair (Amr Al-Nas), the consultation and vote and idea of people are reliable and they are especially noticed: "...and their rule is to take counsel among themselves". Namely, it is people's affair so consultation method is required but not in God's affair and religious injunctions. Also, this counsel may not decrease and increase divine rules so Holy Quran did not express “...and God order to consult among them". Thus, in theory of jurist absolute mandate, people can vote regarding their own private affairs and in public affairs of the country. Divine religion has deemed people as owners of vote and at the same time, leader and fully- qualified jurist (Faqih) also consider people as owners of vote and right in these two areas and they address the requests derived from human's votes and thoughts to the highest level (Javadi Amoli, 1993).

"In accordance with the Quranic prescription [as mentioned in the following verses]:

"And their affairs [are settled] by consultation among them". (Quran, 42).

"And consult them in the affair [of governance" (Quran, 3).

Consultative bodies - such as the Islamic Parliament of Iran, and councils at the level of the province, city, region, district, and village, and the like - will be the country's decision-making and administrative organs." (Constitution, 1979).

"In order to expedite social, economic, public health, cultural, educational and development programs and facilitate other public welfare affairs through the people's participation and in accordance with the local needs, the administration of each village, division, city, town, and province will be supervised by a local Council which will be known as Village, Division, City, Town, or Provincial Council. The members of every council will be elected by its respective population." (Constitution, 1979).

As a result, system of councils starts from the smallest state geographic divisions (i.e. villages) and develops to limit of provinces and within all these orders the people seriously participate in determining their own political, economic, social, and cultural destiny. The scope of the performance domain in these councils has been determined to the extent, which has been stipulated according to Article 103 of Constitution: "Governors of provinces, towns and divisions as well as other officials appointed by the government must abide by the decisions of 
the local Councils made within their jurisdiction."

On the other hand, to supervise over activity of councils and on top of them, "Supreme Council of the Provinces will be established consisting of representatives of the Provincial Councils" (Constitution, 1979).

Within its jurisdiction, the Supreme Council of the Provinces has the right to draft bills and to submit them to the Islamic Parliament of Iran, either directly or through the government. These bills must be examined by the Parliament" (Constitution, 1979).

In Islamic republic of Iran, council system is not limited only to the abovementioned cases, but according to constitutional order: "In order to ensure Islamic justice and cooperation in planning and coordination in expediting matters, councils will be formed, composed of representatives of workers, peasants, other employees and managers, in production units, industrial and agricultural, and of representatives of members of units in educational, administrative, service and other similar sectors" (Constitution, 1979).

Islamic Parliament of Iran is placed in a position higher than Supreme Council of Provinces ${ }^{4}$ where it is composed of direct representatives of the people and it may issue the rules within its jurisdiction that stipulated by the constitution. ${ }^{5}$ The other cornerstone of The Legislature is Guardian Council as well, which includes six jurists and six lawyers ${ }^{6}$ and it is administered by this council. Furthermore, Expediency

4 - Article 12 from State Law for Islamic Councils Organization, approved on 22/11/1982.

5 - The Islamic Parliament of Iran may pass laws in all matters, within the jurisdiction defined by the

Constitution. (Constitution: Article 71)

6 - (Constitution, 1979).
Council also acts like as State council and if we consider it as one of the cornerstones of the Legislature Power, it observes all cornerstones of this power administered by council system.

The limit of councils exceeds from this scope and counseling performance may be seen at the highest level of Islamic system. For example, appointment and election of leader is done by Expert Assembly through consultation between its representatives and decisions are made based on majority of votes and in interim period among the termination of previous leadership career (due to death or resignation or his dismissal) and coming to power by the new leader. Leadership ad hoc Council including the president, head of the Judiciary, and one of jurists from Guardian Council based on election by State Expediency Council, is responsible for leader's tasks provisionally. ${ }^{7}$

\section{Participation in Legislation Area}

In early Islamic periods, legislation was determined by Sharia and the rules were inferred from revelation source and traditions of Pure Imams (A) during this period. However, at present legislation is not derived from Islamic religion and whereas at this time legislation has been implemented for trivial matters and solving executive problem thus it is deemed as a type of decision- making for implementation (Izadehi, 2010). Therefore, in this area and scope of Islamic rules, legislation is executed with respect to principle of council and legalized by assignment from Islamic jurist (Vali Faqih).

Divine religion assumes people as rightholders and at the same time leader and fully- qualified jurist also consider the people as owners of vote and having the

7 (Constitution, 1979). 
right in these two areas (private and public affairs) so it highly addresses the requests derived from their humanistic comments and thoughts; for instance, how the people may live, how to farm, how to do animal husbandry, how they could have fishery and shipping and airline flight, how to establish international relations, with whom they should/ should not transact, how sea legal regime should be and many other affairs so people's affair and their affair in Quranic verses should be implemented based on people's comment and through consultation with them (Javadi Amoli, 1993). Some of articles in Constitution, which denote principle of council in legislation, are as follows: Article 7 assumes councils (Islamic Parliament of Iran, Councils of province, town, city, locality, county, and village) as cornerstones for decision making and administration of State affairs where the member are elected by people's vote. Similarly, some other articles of Constitution, which deal with the possibility of referring directly to people's votes in many important economic, political, social, and culture $^{8}$ issues, emphasize the necessity of referendum in respective of the related approvals to revision of Constitution; ${ }^{9}$ choosing the members in rural, county, urban, and town councils, ${ }^{1}$ election of representatives in Islamic Parliament of Iran, ${ }^{1}$ competency of Islamic Parliament of Iran in legislation for all issues ${ }^{1}$. These articles also denote direct and indirect participation by people in legislation affair that principle of council is one of the important bases of this participation.

8 - (Constitution, 1979).

9 - (Constitution, 1979).

1 - (Constitution, 1979).

1 - (Constitution, 1979).

1 - (Constitution, 1979).

\section{- Participation in Execution of Rules and Administration of Community}

The scope of Islamic jurisprudent leadership (Velayat Faqih) has been separated from national government realm and domain of people's governance in IRI Constitution. In other words, although the main area in this system belongs to Islamic jurisprudent leadership, for national governance in fields of private affairs and issues and properties as well as public and national affairs and properties (not governmental and ruling), certain principles have been allocated to election of president, choosing the members of Expert Assembly, election of representatives in Islamic Parliament of Iran, and election of members in other councils in order to provide their freedom and right of governance while the natural personality of fully- qualified jurist is considered as equal with other citizens without any privilege to them as well in two latter issues, which possesses national governance (Javadi Amoli, 1993). Therefore, it can be mentioned that people's participation in these affairs serve as a type of enforcing governance and administration of affairs based on principle of council.

People can participate in administration of government in several forms out of which is election of agents to administer community's affairs regarding people's affairs and in fact this selection may be considered as a type of participation through council in its general and extended concept. It means that Islamic jurist Vali Faqih (who is the highest executive position in Constitution) consults with the people in administration of community's affairs. For example, he assigns president (as elected by people) for administration of State executive affairs. As Ayatollah Javadi Amoli mentions: 
"People's voting is in fact the consultation with the people. President is elected by the people and people choose representatives of Expert Assembly and deputies of Islamic Parliament of Iran, but in order to legalize all these groups, the competency of Expert Assembly candidates and presidential candidates should be verified first by the appointed members of leader. So, under these conditions legitimacy is demonstrated and the prestige of people's freedom is reserved" (Javadi Amoli, 1993). Even beyond this, Islamic jurist and fullyqualified leader is elected and determined through council and by expert representatives of the people.

The article six is the paramount principle of Constitution, which denotes participation of people in all political and social affairs. It has been expressed in this article that:

"The country's affairs in the Islamic Republic of Iran must be managed on the basis of public opinion as expressed through elections, including the election of the President, the representatives of the Islamic Parliament of Iran, and the members of the councils, and the like, or through referenda, in cases specified in other articles of this law." Although in article 6 it has not been discussed about election of leader, since in article 5 regarding the principle of Islamic Jurisprudent leadership (Velayat Faqih), it has been highlighted that election of Islamic jurist be realized based on article 107. Thus, role of public votes is also identified in election of leader since according to this article "Expert Assembly shall be responsible for determination of leader".

Likewise, according to Clause VIII from article 3, the government shall employ all its facilities and efforts for people's participation in determining their own political, economic, social, and cultural destiny.

\section{- Role of People' Participation in Government in Theory of Jurist's Proxy}

In theory of jurist's proxy, since people play an essential role in legitimacy of ruler and realization of government based on proxyship. They will also play a main role in political participation and enforcement of the governance a fortiori. Although the quality of people participation in determination of political destiny has not been mentioned in details and clearly in theory of jurist's proxy, the position and role of people could be inferred from some comments of the founder of this theory in the book about enforcement of governance. Dr. Mehdi Hayeri writes in his book: "He (human) should be benefitted from all the rights, which have been assumed and proved for human being including freedom in decision and will all the times." (Hayeri Yazdi, 1994).

Similarly, as another point, he states about the people's role in political participation based on proxyship contract that: "Under the supervision and control of his/ her client, the advocate always not only fulfills the responsibilities within the limits of his/ her proxyship but also s/he has no right to violate from the domain of powers of his/ her advocacy and representation and it is a matter of fact that whatever the advocate acts in line with his/ her proxyship and agency by the order of joint owners should be for the sake of defense and discretions and rejecting the adverse effects for each of his/ her clients so that he would return the result of activities caused by his/ her representation equally to each of those clients and individuals and duly for their joint proprietorship." (Hayeri Yazdi, 1994).

Rather than referring to people's role to participate in the government in another 
point of book, he acknowledges this fact that people may make the mistake in election of ruler and be ensnared in devil's deception. "This is the people who may occasionally elect their own ideal subject as a perfect human for ruling in the country by means of their duly choice so that to create a model of utopia while in another time they may be entrapped by deception and trickery of human- like devils and gone astray from the right path and factual thought and this will not result in anything for them but ignorance and corruption as consequence; only this people and obliged individuals should identify the most perfect and competent person from their society that is probably prophet or Imam as they make efforts to meet their own well-being and for family and they should elect those people for political ruling in their country. " (Hayeri Yazdi, 1994).

Regarding people's participation in the field of legislation, he writes: "All those , who share in ownership this land, should assign their own representation to those candidates that possess special skill, intelligence, and capability for this purpose so by selection of this representation from the votes of joint owners of the country or through governance of the majority group over the minority, the first foundation is laid for the conventional and legislative system to emerge and system of conventional domestic security regulations and disciplines for foreign contacts and relations and what is expedient and beneficent for the main owners of the country will be legalized and then implemented." (Hayeri Yazdi, 1994).

For the sake of brevity, and according to what mentioned, the paramount bases of necessity for people's participation in enforcement of governance in theory of jurist absolute mandate is surely to reserve Islamic system and its effectiveness as well as the necessity for observance of Islamic and Muslims' expediencies via consultation and principle of counseling. Of course, the reasons for people's political participation in enforcement of governance may refer to other principles such as Enjoining of the goods and Prohibition of the evils, advice, and the like. Alternately, in theory of jurist's proxy, the quantity and quality of people's participation in establishment of the government may basically depend on content and terms of the concluded contract between people with the ruler as well as the expediencies of human and natural rights (i.e. human rights).

\section{Conclusion}

It can be briefly concluded from sum of aforementioned subjects in this paper that according to the acceptable basis in each of these two doctrines, some similarities and differences may form upon definition of people's position and role which is attached for the people in each of these theories to realize government and enforcement of its power. So, the foremost cases of them can be expressed as follows: In theory of jurist absolute mandate, the legitimacy of government and Islamic jurist leadership is originated from God's order and command and to prove this point, the people essentially play no role in realization and establishment of the government. However, in doctrine of jurist's proxy that is based on will and wish of the people or majority of them, the people play a crucial role in realization and creation of government so one could consider the government as the product of their will and their creature. Likewise, to prove it, establishment, objective realization, acceptability, authority, and stability of the government by the people is the common point in both theories so 
the government has no right to impose their ruling by force and deceiving people. On the other hand, in theory of jurist absolute mandate, the paramount bases of necessity for people's participation in enforcement of the governance is certainly the obligation for protection from Islamic system and its effectiveness as well as the requisite for observance of Islamic and Muslim expediencies by consultation and principle of council. Of course, the reasons for necessity of people's political participation in enforcement of governance may return to other principles such and Enjoining of the goods and forbidding of the evils, advice, and the like so their details is beyond the scope and capacity of this study. In contrast, in theory of jurist's proxy, government and politics are exclusively a public phenomenon, which acquire their validity and arbitrary existence from people's request basis. Thus, since people of any nation are joint owners of that land, according to rule of absolute legal power of owner by dominion, they delegate the proxyship for political administration of the society and peaceful symbiosis in order to manage and lead the given community. Therefore, the extract of reasons that are meant by founder of this theory may refer to ownership and governance of people over their own land and destiny and assigning of their proxyship to the ruler and with the aim of peaceful symbiosis and providing security and justice (not necessarily execution of divine orders and proximity of community to God) so the quantity and quality of people's participation in enforcement of governance may essentially depend on content and terms of the concluded contract among people and ruler as well as the expediencies of human and natural rights (Human Rights). Thus, the scope and limits of ruler's powers as well as people's role in enforcement of power should be tracked in the agreement between them.

\section{References}

The Holy Quran

Arasta, M.J. (2005). The people and establishment of Islamic system, Journal of Islamic Revolution Studies, 2: 85-114

Izadehi, S.S. (2010). The supervision over power in political jurisprudence, $2^{\text {nd }}$ Ed., Qom: Islamic sciences and culture research center.

Javadi Amoli, A. (1993). Islamic jurisprudence; leadership in Islam, $3^{\text {rd }} \mathrm{Ed}$. , Tehran: Raja Pub.

Hayeri Yazdi, M. (1994). Wisdom and government, London: Shadi Pub.

Tabatabaei, S.M.H. (2003). Al-Mizan exegesis, Ed. Moosavi Hamedani, S.M.B, Qom: Islamic Publication Office (Qom Society of Instructors of Islamic Seminary (HOUZEH).

Moosavi Khomeini, R. (2006). Imam's Sahifeh, Tehran: Institute for preparation and publication of Imam Khomeini's (RA) works.

Noori, H.I.M. (1988). "Mostadrak AlVasayel VA Mostanbat Al Masayel (Commentaries of instruments and inferred issues), Alul-Al-Beit (A.S) institute, Dar AlEhya Al-Torath, Beirut (Lebanon).

How to cite this article: Saeed Abdollahyar, Alireza Masihpoor, The Evaluation and Comparison of People's Role in Two Doctrines of Jurist Absolute Mandate and Proxy of Jurist. International Journal of Advanced Studies in Humanities and Social Science, 2019, 8(4), 350-361. http://www.ijashss.com/article_84383.html 